\title{
Change of the content and stores of humus in sod-podzolic sewed soil at different fertilizer systems
}

\author{
M. Datsko \\ Institute of Water Problems and Melioration
}

The purpose. To study productivity of different fertilizer systems (mineral, organic and organo-mineral) in short crop rotations in view of assessment of change of the content and stores of humus in sod-podzolic sandy loam soil on sewed lands. Methods. Field - study of influence of fertilizer systems on change of humus state of sod-podzolic soil, laboratory - determination of the content of humus, mathematical-andstatistical - analysis of variance. Results. By probes it is proved that the most essential incremental va-I ues of the content and stores of humus is registered in soils under field crop rotation. Conclusions. Long (more than 30-years) importation of $20 \mathrm{t} /$ hectare of crop rotation area of muck and $10 \mathrm{t} /$ hectares of muck together with green manure crop promoted essential augmentation of the content and stores of humus in 2 short crop rotations.

Key words: content and stores of humus, sod-podzolic soils, short crop rotations, sewed soils, fertilizer systems.

The issue proceeds of organic matter to stop land degradation, conservation and expanded reproduction significantly worsened in the past decade, since the process of reform of the agricultural production in Ukraine scored low stability and efficiency of industrial relations changes in quality of soil, violation of ecological balance of the environment and the deterioration of hydrothermal conditions.

At the present stage of agricultural production is an urgent problem of reducing the rate of degradation and stabilization of soil fertility, which occurred due to violation of crop rotation, ignoring the rules of agriculture, including the return of organic matter and nutrients [Ошибка! Источник ссылки не найден., Ошибка! Источник ссылки не найден., Ошибка! Источник ссылки не найден.].Of particular interest is a decrease of humus content in the soils of Polesie of Left Bank. To improve the situation it is necessary to take urgent measures for reproduction of soil fertility on the basis of the return loss and optimize the humus state[Ошибка! Источник ссылки не найден., Ошибка! Источник ссылки не найден., Ошибка! Источник ссылки не найден., Ошибка! Источник ссылки не найден., Ошибка! Источник ссылки не найден.]. According to the data G.A. Mazur[Ошибка! Источник ссылки не найден.], the optimal values of the content of humus in the sod-podzolic sandy soils should be $1.6-1.8 \%$.

The actual content of humus in arable soils Polesie of Left Bank depends on the granulometric structure, and is within $0.6-1.8 \%$ but this is not enough for optimization of agro physical and agrochemical properties of the root zone. The problem of increasing the humus content in the soils of Polesie becomes paramount differences in soil with low humus content, which include a sod-podzolic soils[Ошибка! Источник ссылки не найден., Ошибка! Источник ссылки не найден., Ошибка! Источник ссылки не найден.].The development of soil formation processes in these soils is due to the nature of the biological cycle of depleted nutrients and conditions of humification on the background periodically flush the water regime. Therefore refers to such soils low productive [Ошибка! Источник ссылки не найден., Ошибка! Источник ссылки не найден.].Therefore, the choice of reliable testing methods and ways to ensure the content playback and stocks of organic matter in the soil is very relevant [Ошибка! Источник ссылки не найден., Ошибка! Источник ссылки не найден.].

With the decline of mineral and organic fertilizers and the traditional with the increase of organic matter in the soil deficiency becomes very important use of the optimum combination of certain types of fertilizers, including manure, green manure, mineral fertilizers, which affect the change in the content and humus reserves in the system korotkorotatsionnyh rotations. Effective should be considered, such fertilization 
system, which provide a stable flow of organic matter on the condition of the expanded reproduction of soil fertility.

Purpose of work - to investigate efficiency of different systems fertilizers (mineral, organic and organomineral) in korotkorotatsionnyh rotations based on an assessment of reserves and changes in the content of humus in the sod-podzolic sandy loam soil on drained lands.

Materials and methods of research. Studies on the effects of various fertilizer systems were carried out in 2012-2014 years. On the basis of the stationary experience of the Institute of Agricultural Microbiology and Agro-Industrial Production of the National Academy of Sciences in two short-rotation crop rotations. The placement of crops in crop rotations is as follows:

1. Fetal replacement crop rotation: 1 - clover, 2 - winter wheat, 3 - potato, 4 - spring wheat.

2. Grain crop rotation: 1 - lupine for grain, 2 - winter rye, 3 - corn for grain, 4 - oats.

On the background of control (Control), 3 fertilizer systems with such fertilizer variants (mediumrotation rate) were investigated:

1 - organic system: manure $10 \mathrm{t} / \mathrm{ha}$ (Mr 10); Manure $20 \mathrm{t} / \mathrm{ha}$ (Mr 20); sederal culture of narrow-leaved lupines5 t/ha (Sd 1); Manure $10 \mathrm{t} / \mathrm{ha}+$ siderats rye winter $(\mathbf{M r} \mathbf{1 0}+\mathbf{S d} \mathbf{2})$;

2 - mineral $\mathrm{N}_{60} \mathrm{P}_{64} \mathrm{~K}_{71}\left(\mathbf{N}_{60} \mathbf{P}_{64} \mathrm{~K}_{71}\right)$;

3 - organo-mineral: sederal culture of narrow-leaved lupines $+\mathrm{N}_{60} \mathrm{P}_{64} \mathrm{~K}_{71}\left(\mathbf{S d} \mathbf{1}+\mathbf{N}_{60} \mathbf{P}_{64} \mathrm{~K}_{71}\right)$; manure 10 $\mathrm{t} / \mathrm{ha}+\mathrm{N}_{60} \mathrm{P}_{64} \mathrm{~K}_{71}\left(\mathrm{Mr} \mathbf{1 0}+\mathrm{N}_{60} \mathrm{P}_{64} \mathrm{~K}_{71}\right)$.

The investigated site, located within the dried system "Khreshchatoe", which is subordinated to Kozeletsky interdistrict management of water management in the Chernigov region. Sod-podzolic sandy loam soil is dried with such initial agrochemical parameters in the $0-20 \mathrm{~cm}$ layer: humus content is $-1.1 \%$, nitrogen compounds, easily hydrolyzed $97 \mathrm{mg} / \mathrm{kg}$, mobile phosphorus compounds 135 , mobile potassium compounds $80 \mathrm{mg} / \mathrm{kg}$ soil, $\mathrm{pHKCl}$ - 4.9. The humus content was determined according to [15], the reserves - mathematically-statistical.

Results of the research. As a result of three-year studies it was established that in the sod-podzolic soil under the fruit and cereal crop rotations on the option for introducing mineral and sideral fertilizers, it was not possible to change the position of the "mineralization" system of organic matter. In these cases, especially when applying only mineral fertilizers, the content of humus in the rotational crop rotation in comparison with the control decreases by $0.01-0.02 \%$ absolute, and in the grain crop by $0.02-0.03 \%$ (Table 1 ).

\section{Changes in the content and stocks of common humus in various fertilizer systems in the fruit and cereal crop rotations (2012-2014)}

\begin{tabular}{|c|c|c|c|c|c|}
\hline \multirow[b]{2}{*}{ Variant of fertilizer } & \multicolumn{5}{|c|}{ Content $(\%)$ and reserves ( $t / h a)$ of humus } \\
\hline & 2012 & \pm to control & 2014 & \pm to control & $\begin{array}{l}\text { change in } \\
\text { humus content } \\
\text { for 2012-2014, } \\
\pm\end{array}$ \\
\hline \multicolumn{6}{|c|}{ Fetal replacement crop rotation } \\
\hline Control & $1,05 / 31,5$ & - & $1,06 / 31,8$ & - & $+0,01 /+0,3$ \\
\hline Mr 10 & $1,19 / 35,7$ & $+0,14 /+4,2$ & $1,20 / 36,0$ & $+0,14 /+4,2$ & $+0,01 /+0,3$ \\
\hline Mr 20 & $1,41 / 42,3$ & $+0,36 /+10,8$ & $1,46 / 43,8$ & $+0,40 /+12,0$ & $+0,05 /+1,5$ \\
\hline Sd 1 & $1,06 / 31,8$ & $+0,01 /+0,3$ & $1,08 / 32,4$ & $+0,02 / 0,6$ & $+0,02 /+0,6$ \\
\hline Mr $10+\mathrm{Sd} 2$ & $1,33 / 39,9$ & $+0,28 /+8,4$ & $1,38 / 41,4$ & $+0,32 /+9,6$ & $+0,05 /+1,5$ \\
\hline $\mathrm{N}_{60} \mathrm{P}_{64} \mathrm{~K}_{71}$ & $1,04 / 31,2$ & $-0,01 /-0,3$ & $1,04 / 31,2$ & $-0,02 /-0,6$ & $0,00 / 0,0$ \\
\hline $\mathrm{Sd} 1+\mathrm{N}_{60} \mathrm{P}_{64} \mathrm{~K}_{71}$ & $1,14 / 34,2$ & $+0,11 /+3,3$ & $1,18 / 35,4$ & $+0,12 /+3,6$ & $+0,04 /+1,2$ \\
\hline $\mathrm{Mr} 10+\mathrm{N}_{60} \mathrm{P}_{64} \mathrm{~K}_{71}$ & $1,16 / 34,8$ & $+0,09 /+2,7$ & $1,22 / 36,6$ & $+0,16 /+4,8$ & $+0,06 /+1,8$ \\
\hline
\end{tabular}




\begin{tabular}{|c|c|c|c|c|c|}
\hline $\mathrm{LSD}_{0,95}$ & $0,02 / 0,6$ & & $0,03 / 0,9$ & & \\
\hline \multicolumn{6}{|l|}{ Grain crop rotation } \\
\hline Control & $1,03 / 30,9$ & - & $0,99 / 29,7$ & - & $-0,04 /-1,2$ \\
\hline Mr 10 & $1,15 / 34,5$ & $+0,12 /+3,6$ & $1,15 / 34,2$ & $+0,16 /+4,8$ & $0,00 / 0,0$ \\
\hline Mr 20 & $1,38 / 41,4$ & $+0,35 /+10,5$ & $1,40 / 42,0$ & $+0,41 /+12,3$ & $+0,02 /+0,6$ \\
\hline Sd 1 & $1,07 / 32,1$ & $+0,04 /+1,2$ & $1,06 / 31,8$ & $+0,07 /+2,1$ & $-0,01 /-0,3$ \\
\hline Mr $10+\operatorname{Sd} 2$ & $1,32 / 39,6$ & $+0,25 /+7,5$ & $1,36 / 40,8$ & $+0,37 /+11,1$ & $+0,04 /+1,2$ \\
\hline $\mathrm{N}_{60} \mathrm{P}_{64} \mathrm{~K}_{71}$ & $1,01 / 30,3$ & $-0,02 /-0,6$ & $0,96 / 28,8$ & $-0,03 /-0,9$ & $-0,05 /-1,5$ \\
\hline $\mathrm{Sd} 1+\mathrm{N}_{60} \mathrm{P}_{64} \mathrm{~K}_{71}$ & $1,12 / 33,6$ & $+0,09 /+2,7$ & $1,14 / 34,2$ & $+0,15 /+4,5$ & $+0,02 /+0,6$ \\
\hline $\mathrm{Mr} 10+\mathrm{N}_{60} \mathrm{P}_{64} \mathrm{~K}_{71}$ & $1,17 / 35,1$ & $+0,14 /+4,2$ & $1,20 / 36,0$ & $+0,21 /+6,3$ & $+0,03 /+0,9$ \\
\hline $\mathrm{LSD}_{0,95}$ & $0,02 / 0,6$ & & $0,02 / 0,6$ & & \\
\hline
\end{tabular}

This is due to the fact that the prolonged use of mineral fertilizers leads to a more intensive decomposition of organic matter, as confirmed by the studies of O. Kirilesko and A. V. Korneichuk [16].

The most positive changes in the content and reserves of humus took place in the rotational crop rotation against the background of the organic fertilizer system of GN $20 \mathrm{GH} 10+$ SD 2 and especially in the organo-mineral fertilizer - Gn $10+$ N60P64K71, where the humus content and reserves in 2014 increased by $0.05,0,05$ and 0.06 absolute percent or from 1,5 to $1.8 \mathrm{t} /$ ha vs. 2012 .

In grain crop rotation we observe a slightly different trend. In particular, during the years of research on options: control, siderates and mineral fertilizers, the humus content decreased by, respectively, 0,04, 0,01 and 0,05 absolute percent, or 1,2, 0,3 and 1,5 t/a . For joint application of 10 tons per hectare of manure and sideration, the increase was $+0.04 \%(1,2 \mathrm{t} / \mathrm{ha})$.

Compared with the control in the fruit crop rotation (Table 2), a long application of manure in the norm of $20 \mathrm{t} / \mathrm{ha}$ contributed to the greatest increase in the content and reserves of humus - by $0.38 \%$ or $11.4 \mathrm{t} / \mathrm{ha}$. The increase in content and stocks also occurred against the backdrop of manure at a rate of $10 \mathrm{t} / \mathrm{ha}$ in conjunction with siderat $(0.3 \%$ or $9 \mathrm{t} / \mathrm{ha})$. For the introduction of mineral fertilizers, the humus content is reduced by $0.02 \%$ and its reserves by $0.5 \mathrm{t} / \mathrm{ha}$. The same trend was observed in the grain crop rotation.

\section{Content and reserves of humus in sod-podzolic soil under various fertilizer systems and crop} rotations in the 0-20-cm layer on average for 2012-2014.

\begin{tabular}{|c|c|c|c|c|c|}
\hline \multirow{3}{*}{ Variant of fertilizer } & \multicolumn{5}{|c|}{ Crop rotation } \\
\hline & \multicolumn{2}{|c|}{ Fetal replacement crop rotation } & \multicolumn{2}{|c|}{ Grain crop rotation } & \multirow{2}{*}{$\begin{array}{l} \pm \text { to grain crop } \\
\text { rotation, } \%, t / h a\end{array}$} \\
\hline & $\%$ & $\begin{array}{l} \pm \text { to control, } \\
\%, \mathrm{t} / \mathrm{ha}\end{array}$ & $\frac{\%}{\mathrm{t} / \mathrm{ha}}$ & $\begin{array}{l} \pm \text { to control, } \\
\%, \mathrm{t} / \mathrm{ha}\end{array}$ & \\
\hline Control & $\frac{1,06}{31,7}$ & - & $\frac{1,01}{30,3}$ & - & $\frac{+0,05}{+1,4}$ \\
\hline Mr 10 & $\frac{1,2}{35,9}$ & $\frac{+0,14}{+4,2}$ & $\frac{1,15}{34,5}$ & $\frac{+0,14}{+4,2}$ & $\frac{+0,05}{+1,4}$ \\
\hline Mr 20 & $\frac{1,44}{43,1}$ & $\frac{+0,38}{+11,4}$ & $\frac{1,39}{41,7}$ & $\frac{+0,38}{+11,4}$ & $\frac{+0,05}{+1,4}$ \\
\hline Sd 1 & $\frac{1,07}{32,1}$ & $\frac{+0,01}{+0,4}$ & $\frac{1,07}{32}$ & $\frac{+0,06}{+1,7}$ & $\frac{0}{+0,1}$ \\
\hline Mr $10+$ Sd 2 & $\frac{1,36}{40,7}$ & $\frac{+0,3}{+9,0}$ & $\frac{1,34}{40,2}$ & $\frac{+0,33}{+9,9}$ & $\frac{+0,02}{+0,5}$ \\
\hline $\mathrm{N}_{60} \mathrm{P}_{64} \mathrm{~K}_{71}$ & $\frac{1,04}{31,2}$ & $\frac{-0,02}{-0,5}$ & $\frac{0,99}{29,6}$ & $\frac{-0,02}{-0,7}$ & $\frac{+0,05}{+1,6}$ \\
\hline
\end{tabular}




\begin{tabular}{|l|l|l|l|l|l|}
\hline Sd 1 + N ${ }_{60} \mathrm{P}_{64} \mathrm{~K}_{71}$ & $\frac{1,16}{34,8}$ & $\frac{+0,1}{+3,1}$ & $\frac{1,13}{33,9}$ & $\frac{+0,12}{+3,6}$ & $\frac{+0,03}{0,9}$ \\
\hline \multirow{2}{*}{$\mathrm{Mr} 10+\mathrm{N}_{60} \mathrm{P}_{64} \mathrm{~K}_{71}$} & $\frac{1,19}{35,7}$ & $+0,13$ & $\frac{1,19}{35,6}$ & $+0,18$ & $\frac{0}{+0,1}$ \\
\cline { 2 - 6 } & $\frac{0,03}{2,0}$ & $\frac{0,02}{0,6}$ & & $\frac{0,04}{1,2}$ \\
\hline
\end{tabular}

\section{Conclusions}

The results of the conducted studies showed that losses of humus in sod-podzolic sandy loamy soil can be compensated only due to the constant circulation of the maximum amount of organic substances in the fertilizer-plant soil system. Long-term (more than 30 years) application of 20 tons per hectare of syvozminnoi area of manure and 10 tons per hectare of manure, together with siderat, contributed to a significant increase in humus content and reserves in two short-rotation crop rotations. So, the organic fertilizer system with application of 20 tons per hectare of syvozminnoi area of manure from the point of view of return of organic substances proved to be the most optimal in both crop rotations, and long-term application of mineral fertilizers leads to losses of humus content and reserves.

\section{Bibliography}

1. Gruntozakhysna biolohichna systema zemlerobstva v Ukrayini/[M.K. Shykula, S.S. Antonets', A.D. Balayev ta in.] ; za red. M.K. Shykuly. -K., 2000. - 388 s.

2. Royik M.V. Suchasni naukovo obgruntovani pidkhody do vykorystannya zemli/M.V. Royik/Nisnyk ahrarnoyi nauky. - 2003. - № 1. - S. 5-13.

3. Sayko V.F. Stan zemel'nykh uhid' ta polipshennya yikh vykorystannya/V.F. Sayko//Zbirnyk naukovykh prats' NNTs «Instytut zemlerobstva UAAN». - K., 2005. - Spetsvypusk. - S. 3-11.

4. Yermolayev M.M. Zminy humusovoho stanu dernovo-pidzolystoho gruntu pid vplyvom udobrennya u sivozminakh Polissya /MM. Yermolayev. V.V. Khokhlov //Visnyk ahrarnoyi nauky. - 2013. - №1.- S. 11-14.

5. Nosko B.S. Humusnoe sostoyanye pochv Ukraynы y puty eho rehulyrovanyya/B.S. Nosko, A.A. Batsula, H.Ya. Chesnyak//Pochvovedenye. - 1992. - № 10. - S. 33-39.

6. Strel'chenko V.P. Vidtvorennya humusu $v$ ahroekosystemakh Polissya/ [V.P. Strel'chenko, A M. Bovsunovs'kyy, O.P. Stetsyuk ta in.]//Visnyk ahrarnoyi nauky. - 2000. - № 7. - S. 9-13.

7. Эrenfryd E. Pfayfer Plodorodye zemly, eho podderzhanye y obnovlenye/Эrenfryd E. Pfayfer; [perevydannya]. - L'viv: Federatsiyaorhanichnohorukhu, 2010. - $334 \mathrm{~s}$.

8. Mazur H.A. Ekolohichni problemy rozshyrenoho vidtvorennya rodyuchosti dernovo-pidzolystykh gruntiv Polissya /H.A. Mazur//Mater. konf. «Ekolohiya Polissya: problemy, suchasnist', maybutnye». Kharkiv - Luts'k. - 1993. - Ch. 1. - S. 16-22.

9. Mazur H.A. Vidtvorennya i rehulyuvannya rodyuchosti lehkykh gruntiv : [monohrafiya]/H.A. Mazur ; za nauk. red. akad. UAAN V.F. Sayka. - K.: Ahrarna nauka, 2008. - 308 s.

10. Osoblyvosti dehradatsiyi sil's'kohospodars'kykh zemel' Chernihivs'koho Polissya/l.P. Yatsuk, A.M. Lishuk//Ahroekolohichnyy zhurnal. - 2014. - № 1. - S.49-55.

11. Tarariko O.H. Ahroekolohichnyy stan gruntiv ta kontrol' za yikh rodyuchistyu/O.H. Tarariko, V.O. Hrekov, L.V. Dats'ko//Ahroekolohichnyy zhurnal. - 2013. - № 3. - S. 39-44.

12. Stan rodyuchosti gruntiv Ukrayiny ta prohnoz yoho zmin za umov suchasnoho zemlerobstva/ [V.V. Medvedyev, S.Yu. Bulyhin, S.A. Balyuk ta in.] ; Za red. akad. UAAN V.V. Medvedyeva, doktora s.-h. nauk V.M. Lisovoho. - Kharkiv: ShTRIKh, 2001. - 98 s.

13. Rodyuchist' gruntu i efektyvnist' vykorystannya rilli v sivozminakh Polissya zalezhno vid sposobiv zastosuvannya solomy na dobryvo/[I.V. Hrynyk, O.I. Bakun, Yu.O. Bakun, O.V. Yehorov ] I/Visnyk ahrarnoyi nauky. - 2009. - № 1. - S. 16-20.

14. Dalal Ram C. Soil Organic Matter, Soil Health and Climate Change/Ram C Dalal, Diane E Allen, K Yin Chan, Bhupinder Pal Singh,//Soil Health and Climate Change. - Springer Berlin Heidelberg, 2011. P. 87-106. - (Series Soil Biology ; v. 29). 
15. Yakist' gruntu. Metody vyznachennya orhanichnoyi rechovyny: DSTU 4289:2004. - [Chynnyy vid 2005-07-01]. - K.: Derzhspozhyvstandart Ukrayiny, 2005. - 9 s. (Natsional'nyy standart Ukrayiny).

16. Kirilesko O. L. Vplyv nasychennya sivozmin bahatorichnymy travamy, zaoryuvannya solomy ta syderativ na balans humusu v gruntakh/O. L. Kirilesko, O. V. Korniychuk//Zemlerobstvo. - 2015. - Vyp. 1. S. 77-81. 